\title{
Pelatihan Videografi Balai Latihan Kerja Al Ittihad dengan Model Project Based Learning
}

\author{
Soetam Rizky Wicaksono ${ }^{1 *}$, Didit Prasetyo Nugroho ${ }^{2}$ \\ ${ }^{1,2}$ Fakultas Sains dan Teknologi, Universitas Ma Cung \\ ${ }^{1}$ soetam.rizky@machung.ac.id , 2didit.prasetyo@machung.ac.id
}

\begin{abstract}
The pandemic outbreak has had an impact on the field of employment in general, so the Al Ittihad BLK (Balai Latihan Kerja or Work Training Centre) is trying to improve the digital skills of the learning participants to be more competitive during and after the pandemic. BLK, whose participants are the majority of alumni from the Al Ittihad Islamic boarding school, is expected to get additional ability to increase competitiveness in the world of work. The Ma Chung University community service team, which had discussed in a brainstorming session with the BLK managers, then agreed to provide videography training with the PBL (Project Based Learning) model with the assumption that the model was better able to increase the enthusiasm for learning and optimize the creative potential of the participants. The training, which was carried out offline for a limited time in the Poncokusumo area, Malang Regency, was proven to be able to improve the skills of the participants in learning and more visible learning outcomes based on the video project made by the participants. So it can be concluded that the implementation of the PBL model in this training process can be more effective in the limited training period.
\end{abstract}

Keywords : Videography, Al Ittihad, Ma Chung University, Project Based Learning

\section{Abstrak}

Masa pandemi telah berdampak terhadap bidang ketenagakerjaan secara umum, sehingga BLK (Balai Latihan Kerja) Al Ittihad berusaha meningkatkan kemampuan digital para peserta belajar untuk dapat lebih bersaing pada masa dan pasca pandemi.BLK yang para pesertanya mayoritas alumni dari pesantren Al Ittihad tersebut diharapkan mendapatkan tambahan kemampuan untuk meningkatkan daya saing di dunia kerja. Tim pengabdian masyarakat Universitas Ma Chung yang telah berdiskusi dalam sesi brainstorming dengan pihak pengelola BLK, kemudian bersepakat untuk memberikan pelatihan videografi dengan model PBL (Project Based Learning) dengan asumsi bahwa model tersebut mampu lebih baik dalam meningkatkan semangat belajar dan mengoptimalkan potensi kreatifitas peserta. Pelatihan yang dilaksanakan secara luring dalam waktu terbatas di daerah Poncokusumo, Kabupaten Malang, terbukti mampu meningkatkan skill para peserta belajar serta lebih terlihat hasil belajar berdasarkan proyek video yang dibuat oleh peserta. Sehingga dapat disimpulkan bahwa pelaksanaan model PBL dalam proses pelatihan ini bisa lebih efektif dalam masa pelatihan yang terbatas.

Kata Kunci: Videografi, Al Ittihad, Universitas Ma Chung, Project Based Learning

*Penulis Korespondensi : Soetam Rizky Wicaksono

\section{PENDAHULUAN}

Pandemi Covid-19 yang pada saat artikel ini ditulis telah mencapai usia nyaris satu tahun, telah berdampak serius terhadap berbagai bidang kehidupan. Baik dampak positif maupun negatif, semuanya menjadikan banyak perubahan dalam kehidupan sehari-hari . Salah satu dampak tersebut adalah di bidang ketenagakerjaan yang mengalami keguncangan luar biasa di masa pandemi. Pada saat awal pandemi, LIPI mencatat setidaknya 2 juta tenaga kerja terdampak negatif atau dirumahkan (LIPI, 2020). Kemudian pada tahun 2021, angka tersebut meningkat berkali lipat 
menjadi lebih dari 9 juta tenaga kerja yang terdampak pandemi (Violetta, 2021).

Hal tersebut menunjukkan bahwa efek dari pandemi terhadap sektor tenaga kerja sangat terasa memukul masyarakat. Terlebih untuk usia produktif yang diperkirakan terdampak hingga lebih dari 27 juta orang (Violetta, 2021). Namun demikian, pemerintah telah berupaya dengan sangat keras untuk mengatasi masalah tersebut, baik dengan program kartu pra kerja, keringanan dan insentif pajak di beragam sektor ataupun dengan kebijakan padat karya.

Di sisi lain, masyarakat juga berupaya secara mandiri dalam komunitas masing-masing untuk mengatasi masalah ini melalui pelatihan-pelatihan yang diadakan secara daring ataupun luring, baik atas nama lembaga resmi pendidikan, lembaga ketenagakerjaan ataupun lembaga swasta independen. Kepedulian yang sama ditunjukkan oleh yayasan Al Ittihad yang berlokasi di Poncokusumo Kabupaten Malang. Yayasan yang diampu oleh pondok pesantren Al Ittihad tersebut memiliki lembaga BLK atau Balai Latihan Kerja yang bertujuan untuk mempersiapkan generasi usia produktif dalam menghadapi tantangan dunia kerja, khususnya di masa pandemi.

BLK Al Ittithad yang pada umumnya menampung alumni dari pondok pesantren putri Al Ittihad berupaya untuk memberikan kemampuan ekstra kepada peserta didiknya. Kemampuan yang dimaksud adalah kemampuan yang mampu membantu untuk bekerja, khususnya di masa pandemi dan pasca pandemi. Berdasarkan hasil brainstorming dengan pihak pengelola BLK, maka dapat disimpulkan bahwa kemampuan ekstra yang dibutuhkan adalah kemampuan di aspek digital.

Kemampuan di aspek digital tersebut merupakan kebutuhan yang cukup vital saat ini bagi generasi muda, dikarenakan kebutuhan saat ini dalam menghadapi revolusi industri 4.0 (Gusdwisari, 2020; Mulyana, Pratama and Ismail, 2020). Sehingga pihak tim mampu meyakinkan pengelola BLK bahwa pelatihan ini memang sangat layak diadakan.

Pelatihan yang dilaksanakan sebagai aktifitas pengabdian masyarakat ini dilakukan secara luring meski masih dalam masa pandemi. Hal ini dikarenakan pelatihan secara daring secara umum masih sulit untuk diterima, terlebih di Indonesia yang banyak mengalami kendala dari beragam hal (Agung and Surtikanti, 2020; Febrianto, Mas'udah and Megasari, 2020). Sehingga diputuskan bahwa dalam kasus ini, penerapan pelatihan luring masih menjadi solusi yang terbaik.

Dengan adanya keputusan penyelenggaraan secara luring, maka pihak tim wajib berimprovisasi agar pelatihan dapat berjalan seefektif mungkin dalam waktu yang singkat. Hal ini mengingat keterbatasan akibat efek pandemi, sehingga pelatihan hanya bisa dilaksanakan dengan waktu yang terbatas.

Berdasarkan observasi awal dari tim dan hasil brainstorming dengan pihak pengelola BLK, maka diputuskan pemilihan model PBL atau Project Based Learning. Pemilihan PBL ini dengan dasar bahwa target pencapaian hasil pelatihan dari pihak pengelola mensyaratkan bahwa peserta diharapkan mampu melakukan proses pembuatan video dari awal hingga akhir. Serta kondisi keterbatasan waktu pelatihan yang tidak memungkinkan untuk secara keseluruhan menggunakan model klasikal.

PBL sendiri lebih cenderung untuk memberikan topik tertentu dari awal kepada peserta belajar agar dapat dikembangkan dengan bimbingan dari guru (Indrawan and Jalinus, Nizwardi, 2018; Mahasneh and Alwan, 2018). Sehingga para peserta belajar dapat lebih fokus terhadap apa yang dikerjakan dan mendapatkan pengalaman belajar yang lebih baik dan berkesinambungan atau dapat dikembangkan lebih lanjut setelah proses belajar formal selesai dilakukan (Kricsfalusy, George and Reed, 2018).

Sehingga PBL diharapkan dapat meningkatkan kreatifitas para peserta belajar (Isabekov and Sadyrova, 2018), serta mampu meningkatkan kemampuan berpikir kritis dari para peserta (Sasson, Yehuda and Malkinson, 2018). Hal tersebut nantinya diharapkan mampu menjadikan para peserta belajar dapat mempraktekkan hasil dari pelatihan secara mandiri.

\section{METODE}

Secara singkat, metode pelaksanaan dari aktifitas pengabdian ini dapat digambarkan dengan diagram berikut:

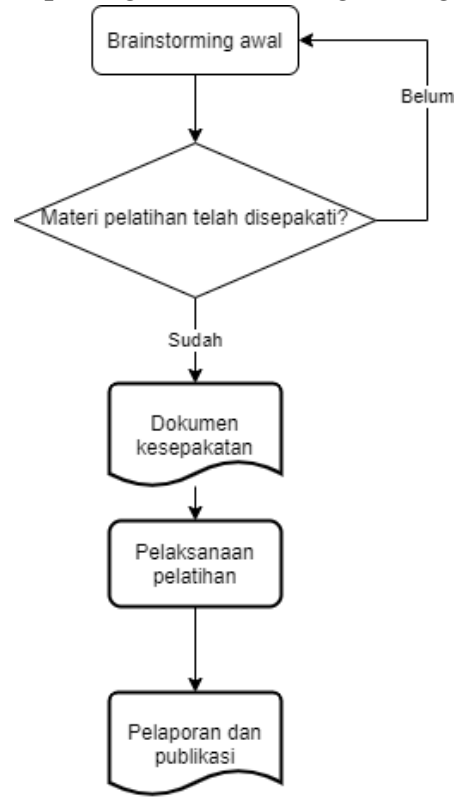

Gambar 1. Flow Proses Pelatihan 
Sebagaimana telah dijabarkan di pendahuluan, langkah pertama adalah dengan melakukan proses brainstorming bersama pengelola BLK untuk menentukan materi pelatihan yang akan dijalankan. Berdasarkan hasil proses tersebut, maka akhirnya disepakati bahwa materi pelatihan yang diberikan adalah mengenai videografi, khususnya mengenai editing video.

Kemampuan editing video ini dipilih dikarenakan dengan adanya penambahan skill bagi para peserta BLK dapat meningkatkan daya saing dalam berkompetisi di era revolusi industri saat ini, khususnya di skill digital (Hamid et al., 2020; Novitasari, 2020). Selain itu, fasilitas yang telah dimiliki oleh pihak BLK, yakni laboratorium komputer yang tersedia, diasumsikan dapat memenuhi spesifikasi yang dibutuhkan dalam proses pelatihan.

Langkah berikutnya dalam pelaksanaan ini adalah dengan adanya dokumen kesepakatan pelatihan antara pihak tim dengan pengelola BLK yang dituangkan ke dalam dokumen resmi, yakni berupa surat permohonan dari pihak BLK ke pihak universitas pengampu tim pengabdian, yakni Universitas Ma Chung Malang, dan juga penugasan resmi dari pihak universitas untuk tim. Dokumen dengan nomor dokumen 0028/MACHUNG/FST/ST.DOSEN/X/2020 ini menegaskan kesepakatan pelaksanaan pelatihan tersebut.

Selanjutnya pelaksanaan pelatihan dilakukan pada bulan Oktober 2020 dengan durasi tiga hari yang dituntaskan dengan pelaporan secara resmi. Pelaksanaan pelatihan beserta hasilnya dibahas dalam bab hasil dan pembahasan.

\section{HASIL DAN PEMBAHASAN}

Aktifitas pelatihan dilaksanakan dalam waktu tiga hari dengan materi tentang teknik pengambilan gambar yang meliputi: (1) pengaturan angle, (2) komposisi, (3) frame size, dan (4) type of shot. Sedangkan materi di hari kedua berisikan tentang teknik editing yang meliputi: (1) pengenalan software Adobe premiere, (2) tool memilih sequence, (3) menata video di timeline, (4) cut and transition, serta (5) color grading. Pada hari terakhir, ditambahkan materi mengenai: (1) menambah musik, (2) menambah teks dan (3) rendering.

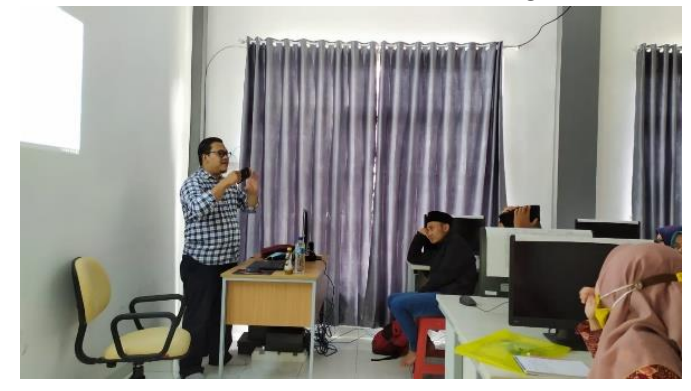

Gambar 2. Pelatihan Hari Pertama
Urutan dari materi ini disusun agar para peserta pelatihan dapat memahami videografi tidak hanya dari teori, tetapi juga dari proses awal pembuatan sebuah video. Sesuai dengan kesepakatan awal mengenai pelaksanaan PBL dalam proes pelatihan, maka setiap peserta dibagi menjadi kelompok untuk membuat proyek video.

Dikarenakan masa pandemi yang membuat ruang gerak terbatas, maka proyek video hanya bisa dilakukan di sekitar lingkungan BLK yang juga sekaligus menjadi homebase pesantren Al Ittihad. Selain itu, juga memudahkan proses shoot yang dilakukan di hari pertama dan kemudian berpindah ke proses editing di hari kedua dan ketiga.

Pelaksanaan pelatihan dengan menggunakan model PBL juga mendorong para peserta belajar untuk aktif berdiskusi di dalam maupun di luar kelas yang berupa laboratorium komputer di BLK. Hal ini membuktikan bahwa PBL memang lebih efektif untuk mendorong peserta belajar lebih termotivasi dalam mencari pengetahuan di luar materi klasikal yang diberikan (Kricsfalusy, George and Reed, 2018).

Pada hari kedua dan ketiga yang secara utuh dilakukan di dalam ruangan atau kelas, pihak pengelola BLK pada akhirnya dapat menyadari bahwa fasilitas laboratorium komputer yang dimiliki dapat lebih dioptimalkan penggunaannya. Hal ini dikarenakan proses editing yang kerap diasumsikan "berat", ternyata dapat dilaksanakan dengan baik,

Hasil dari hari kedua dan ketiga juga membuktikan bahwa para peserta yang seluruhnya merupakan alumni dari SMK dan SMA mampu mengeluarkan potensi kreatifitas yang selama ini tidak mereka ketahui. Sehingga mampu membangkitkan kepercayaan diri dalam mengembangkan diri di kemudian hari dan bersaing di dunia kerja.

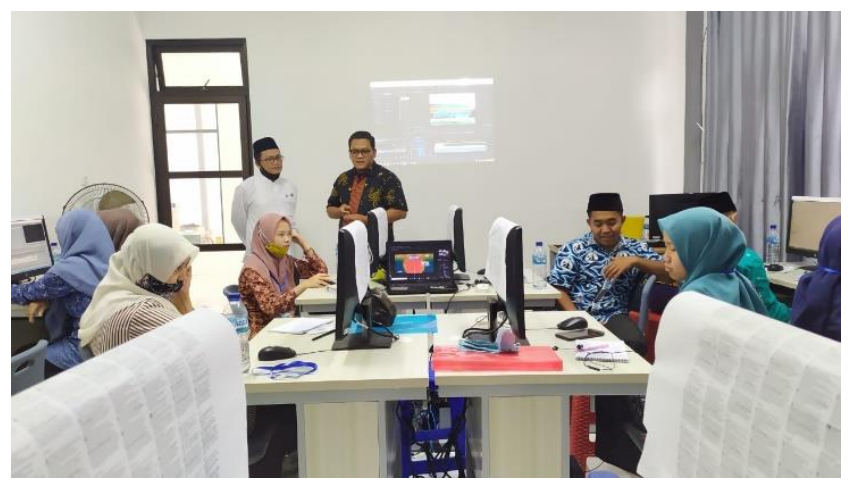

Gambar 3. Pelatihan Hari Kedua

Pelatihan dengan menggunakan model PBL juga dapat memberikan hasil yang lebih baik dibandingkan model klasikal yang biasanya diakhir dengan evaluasi secara tertulis. Sebab dengan pelaksanaan PBL, maka para peserta belajar dituntut untuk menyelesaikan proyek yang pada dasarnya 
dibuat dan dirancang oleh mereka sendiri (Isabekov and Sadyrova, 2018). Sehingga setiap peserta lebih terpacu dan bersemangat dikarenakan mereka mengerjakan proyek yang memang mereka inginkan, bukan proyek yang diwajibkan oleh orang lain.

Hasil dari pengerjaan proyek para peserta ini, meski tidak bisa dikatakan sempurna, menjadi titik awal dari pengembangan diri yang diharapkan oleh pengelola BLK bagi para peserta belajar. Sehingga di kemudian hari muncul semangat untuk tetap belajar meskipun sudah tidak lagi di jalur pendidikan formal.

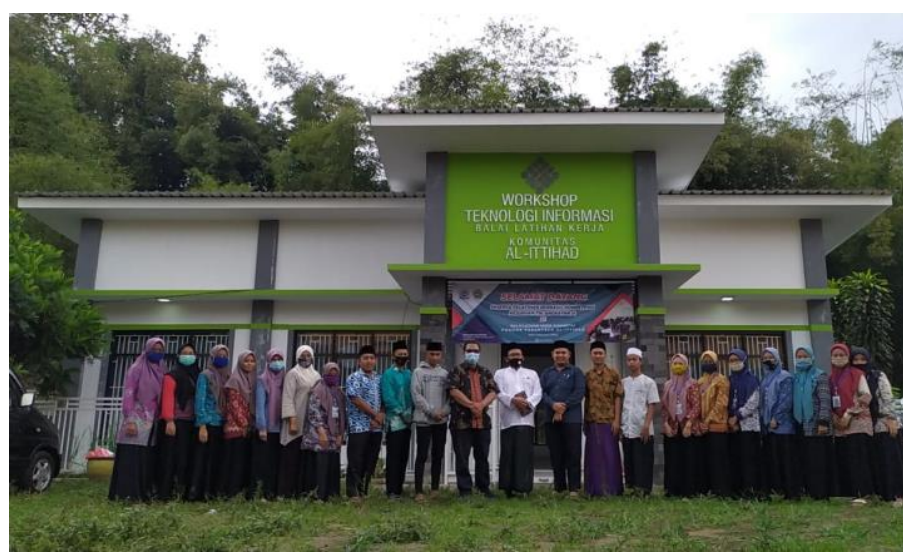

Gambar 4. Pelatihan Hari Terakhir

Evaluasi dari hasil pelatihan ini dapat dijabarkan sebagai berikut: (1) pelaksanaan pelatihan dapat dilakukan sesuai dengan harapan dari pihak pengelola BLK meskipun dalam masa pandemi, namun tetap diselenggarakan secara luring, (2) hasil evaluasi berupa proyek masih kurang terdokumentasi dengan baik, yang seharusnya dapat menjadi portofolio dari peserta dan juga pihak BLK, (3) tidak tersusunnya modul pelatihan yang terstruktur dikarenakan lini masa dari tahap brainstorming ke pelatihan yang begitu singkat, serta (4) kurangnya dokumentasi saat pelatihan berlangsung sehingga mempersulit pelaporan akhir.

\section{KESIMPULAN}

Hasil dari aktifitas pelatihan tersebut dapat disimpulkan cukup berhasil dalam ruang lingkup membangkitkan semangat para peserta BLK untuk meningkatkan kemampuan dalam skill digital secara umum, baik berdasarkan animo peserta saat pelatihan dilaksanakan. Penerapan PBL dapat lebih mengoptimalkan hasil dari pelatihan yang singkat dikarenakan hasil pembelajaran yang lebih komprehensif dibanding pembelajaran secara klasikal. Selain itu dapat disimpulkan bahwa pihak BLK pada akhirnya menyadari tentang urgensi dari skill digital bagi peserta BLK, serta bagaimana cara untuk mengoptimalkan perangkat laboratorium yang telah dimiliki.

Hasil lain yang bisa didapatkan adalah persiapan untuk peserta BLK dalam menghadapi dunia kerja seharusnya beragam dan beradaptasi dengan kebutuhan saat ini khususnya dalam menghadapi revolusi industri. Peningkatan skill digital, baik dalam hal hardskill ataupun kreatifitas harus tetap dilatih agar dapat bersaing di dunia kerja.

\section{UCAPAN TERIMA KASIH}

Ucapan terima kasih atas kerjasama dalam proses pelatihan disampaikan kepada kepala madrasah Al Ittihad, bapak H. Agus Ikhwan Mahmudi. Terima kasih juga disampaikan kepada Kepala Program Studi DKV Universitas Ma Chung dan dekan Fakultas Sains dan Teknologi Universitas Ma Chung yang telah mendukung pelaksanaan pengabdian masyarakat ini.

\section{DAFTAR PUSTAKA}

Agung, A. S. N. and Surtikanti, M. W. (2020) 'Students' Perception of Online Learning during COVID-19 Pandemic: A Case Study on the English Students of STKIP Pamane Talino', SOSHUM: Jurnal Sosial dan Humaniora, 10(2), pp. 225-235. doi: 10.31940/soshum.v10i2.1316.

Febrianto, P. T., Mas'udah, S. and Megasari, L. A. (2020) 'Implementation of online learning during the covid-19 pandemic on Madura Island, Indonesia', International Journal of Learning, Teaching and Educational Research, 19(8), pp. 233-254. doi: 10.26803/ijlter.19.8.13

Gusdwisari, B. (2020) 'Digital Skill Education Concept, Upaya Peningkatan Kualitas Generasi Muda dan Mengurangi Tingkat Pengangguran Menuju SDGs 2030', in Prosiding Seminar Nasional Pendidikan Program Pascasarjana Universitas Pgri Palembang, pp. 216-223.

Hamid, A. A. et al. (2020) 'MEMPERSIAPKAN GENERASI MUDA YANG KREATIF DAN INOVATIF DALAM MENGHADAPI INDUSTRI 4.0 DI RUMAH GEMILANG INDONESIA (RGI) DEPOK', Jurnal Abdimas Tridharma Manajemen, 1(2), pp. 5666.

Indrawan, E. and Jalinus, Nizwardi, S. (2018) 'Review Project Based Learning', International Journal of Science and Research, 8(4), pp. 1014-1018. Available at: www.ijsr.net.

Isabekov, A. and Sadyrova, G. (2018) 'Project-Based Learning to Develop Creative Abilities in Students', in Vocational Teacher Education in Central Asia. Springer. doi: 10.1007/978-3-319. 73093-6_4. 
Kricsfalusy, V., George, C. and Reed, M. G. (2018) 'Integrating problem- and project-based learning opportunities: assessing outcomes of a field course in environment and sustainability', Environmental Education Research, 24(4), pp. 593-610. doi: 10.1080/13504622.2016.1269874.

LIPI (2020) Survei Dampak Darurat Virus Corona terhadap Tenaga Kerja Indonesia. Jakarta. Available at: http://lipi.go.id/berita/single/Survei-Dampak-Darurat-VirusCorona-terhadap-Tenaga-Kerja-Indonesia/22030.

Mahasneh, A. M. and Alwan, A. F. (2018) 'The effect of project-based learning on student teacher self-efficacy and achievement', International Journal of Instruction, 11(3), pp. 511-524. doi: 10.12973/iji.2018.11335a.

Mulyana, M. Y., Pratama, M. A. and Ismail, M. S. (2020) 'Peran Sumber Daya Manusia (Sdm) / Generasi Muda Dalam Menyongsong Revolusi Industri 4.0', Prismakom, 16(1), pp. 3646.

Novitasari, N. (2020) 'Pemberdayaan Masyarakat Sebagai Upaya Menciptakan Generasi Muda Berdaya Literasi Pada Kampung Sinau Kota Malang', Jurnal Akrab, 11(2), pp. 30-41. doi: 10.51495/jurnalakrab.v11i02.348.

Sasson, I., Yehuda, I. and Malkinson, N. (2018) 'Fostering the skills of critical thinking and question-posing in a project-based learning environment', Thinking Skills and Creativity, 29, pp. 203-212. doi: 10.1016/j.tsc.2018.08.001.

Violetta, P. T. (2021) Dampak pandemi COVID-19 luar biasa, 29,12 juta pekerja terdampak, AntaraNews. Available at: https://www.antaranews.com/berita/1992784/dampak-pandemicovid-19-luar-biasa-2912-juta-pekerja-terdampak (Accessed: 27 February 2021) 